\title{
New species of the genera Australochus Khalaim and Pbradis Förster (Hymenoptera: Ichneumonidae: Tersilochinae) from Australia
}

\author{
Новые виды родов Australocbus Khalaim и Pbradis Förster \\ (Hymenoptera: Ichneumonidae: Tersilochinae) из Австралии
}

\begin{abstract}
A.I. Khalaim
А.И. Халаим

Zoological Institute of the Russian Academy of Sciences, St. Petersburg, Universitetskaya nab. 1, Russia. Зоологический институт АН России, Санкт-Петербург, Университетская наб. 1, Россия.

Universidad Autónoma de Tamaulipas, Cd. Victoria, Tamaulipas, México. E-mail: ptera@mail.ru

KEY WORDS: Australia, Australochus, Phradis, new species, taxonomy.

КЛЮЧЕВЫЕ СЛОВА: Австралия, Australochus, Phradis, новый вид, систематика.
\end{abstract}

ABSTRACT. Two new species, Australochus darreni sp.n. and Phradis tselikhae sp.n., are described and illustrated from Australia.

РЕЗЮМЕ. Два новых вида, Australochus darreni sp.n. и Phradis tselikhae sp.n., описаны из Австралии.

\section{Introduction}

The endemic Australian genus Australochus Khalaim, 2004 was known from a single species, A. clypeator Khalaim, 2004, described on the basis of one female [Khalaim, 2004]. This genus was recently re-described, and additional material and colour illustrations of A. clypeator were provided [Khalaim, 2015]. Nothing is known about the biology of the genus.

Phradis Förster, 1869 is a moderately large, predominantly Holarctic genus with a few species in the Afrotropical, Oriental and Neotropic regions [Yu et al., 2012]. Moreover, five undescribed species of Phradis were mentioned from Australia by Gauld [1984]. In Europe, some species of Phradis are common parasitoids of sap beetle larvae of the genus Meligethes Stephens, 1830 (Nitidulidae).

The aim of this study is to descibe one species of Australochus and one species of Phradis from Australia.

\section{Material and Methods}

Material for this study was obtained from the Texas A\&M University, Texas, U.S.A. (TAMU) and the Zoological Institute of the Russian Academy of Sciences, St. Petersburg, Russia (ZISP). The morphological terminology is mostly that of Khalaim [2011]. Photographs were taken at ZISP with a Canon EOS 70D digital camera attached to an Olympus SZX10 stereomicroscope; images were combined using Helicon Focus Pro software.
Results

\section{Australochus darreni Khalaim, sp.n.} Figs 2-9.

MATERIAL EXAMINED. Holotype: female, South Australia, Melrose, 19.II.1990, coll. R. Wharton (TAMU).

COMPARISON. The new species is very similar to A. clypeator but differs from this species by its strongly tapered and twisted mandible with lower tooth short and curved downwards (Fig. 3; compare with Fig. 1 in A. clypeator), fewer number of antennal flagellomeres (20 in A. darre$n i$ sp.n. and 28 in A. clypeator), weak foveate groove of mesopleuron (Fig. 8; compare with A. clypeator [Khalaim, 2015: Fig. 9]), propodeum with apical area flat (distinctly impressed along midline in A. clypeator), fore wing with abscissae of radius meeting at right angle (Fig. 9; compare with A. clypeator [Khalaim, 2015: Fig. 10]), ovipositor with two dorsal subapical teeth [one tooth in A. clypeator, see Khalaim, 2015: Fig. 16], and mesosoma and metasoma extensively brownish orange (Figs 2, 7).

DESCRIPTION. Female. Body length $3.6 \mathrm{~mm}$. Fore wing length $2.7 \mathrm{~mm}$.

Head strongly rounded behind eyes in dorsal view (Fig. 5 ); temple 0.5 times as long as eye width. Eyes glabrous. Clypeus (Fig. 6) lenticular, 3.2 times as broad as long, flat, entirely smooth and shining, with scattered punctures near its upper margin, separated from face by thin and sharp groove. Mandible (Fig. 3) twisted, with upper tooth 3.0 times longer than the lower; lower tooth small and curved downwards; mandible at level of teeth 0.35 times its width at base. Malar space short, 0.4 times as long as basal mandibular width (Fig. 3). Antennal flagellum (Fig. 4) filiform, with 20 flagellomeres; all flagellomeres 1.3-1.5 times as long as broad; flagellomeres 4 and 5 bearing conspicuous and flagellomere 6 small finger-shaped subapical structures on outer side. Face with very weak convexity centrally. Face and frons with distinct and moderately dense, vertex with fine and sparse, and temple with very fine and very sparse punctures on smooth and shining background. Occipital carina complete, mediodorsally dipped. Hypostomal carina absent. 
Mesoscutum polished, with shallow scattered punctures anteriorly. Scutellum convex in lateral view (Fig. 7), with lateral longitudinal carinae developed only at its extreme base. Notaulus distinctly impressed anterolaterally. Mesopleuron finely punctate on polished background; punctures fine but distinct centrally (above foveate groove), shallow and mostly indistinct peripherally. Foveate groove extending more or less in centre of mesopleuron, oblique, broad but shallow, with distinct transverse wrinkles (Fig. 8). Dorsolateral area of propodeum smooth and shining, with shallow inconspicuous punctures. Propodeum mediodorsally with broad, irregularly wrinkled furrow which is 0.4 times as long as apical area. Propodeal spiracle separated from pleural carina by almost 2.5 times diameter of spiracle (Fig. 7). Apical area flat, narrowly rounded anteriorly; apical longitudinal carinae complete, reaching transverse carina anteriorly.

Fore wing (Fig. 9) with second recurrent vein postfurcal. Intercubitus long, slightly thickened, somewhat longer than abscissa of cubitus between intercubitus and second recurrent vein. First abscissa of radius 1.1 times as long as width of

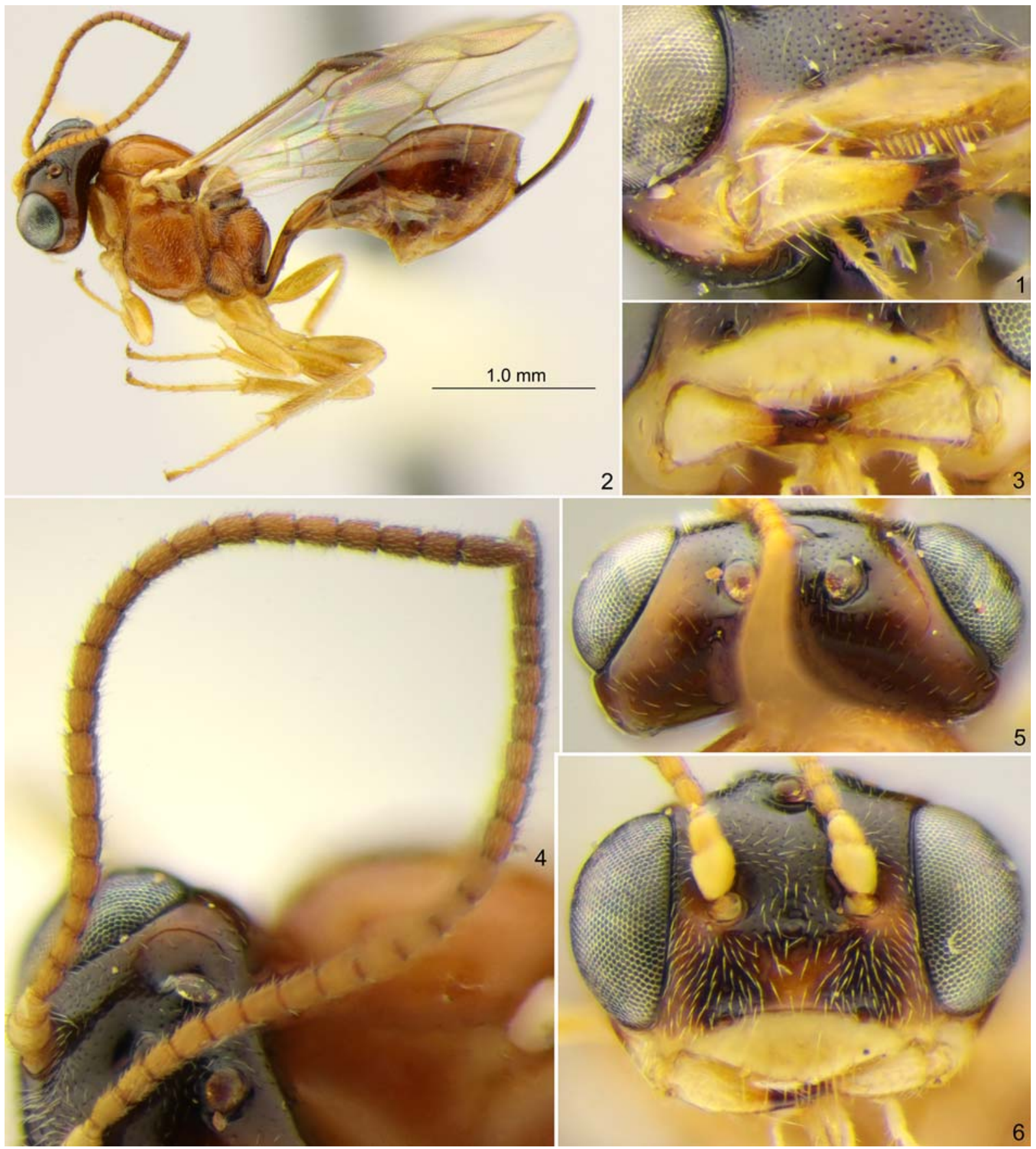

Figs 1-6. Australochus spp., females, holotypes:1 - A. clypeator; 2-6 - Australochus darreni sp.n.; 1, 3 - mandible, ventral view; 2 - habitus, lateral view; 4 - antennae; 5 - head, dorsal view; 6 - head, front view.

Рис. 1-6. Australochus spp., самки, голотипы: 1 - А. clypeator; 2-6 - Australochus darreni sp.n.; 1, 3 - мандибула, вид снизу; 2 - габитус, вид сбоку; 4 - антенны; 5 - голова, вид сверху; 6 - голова, вид спереди. 


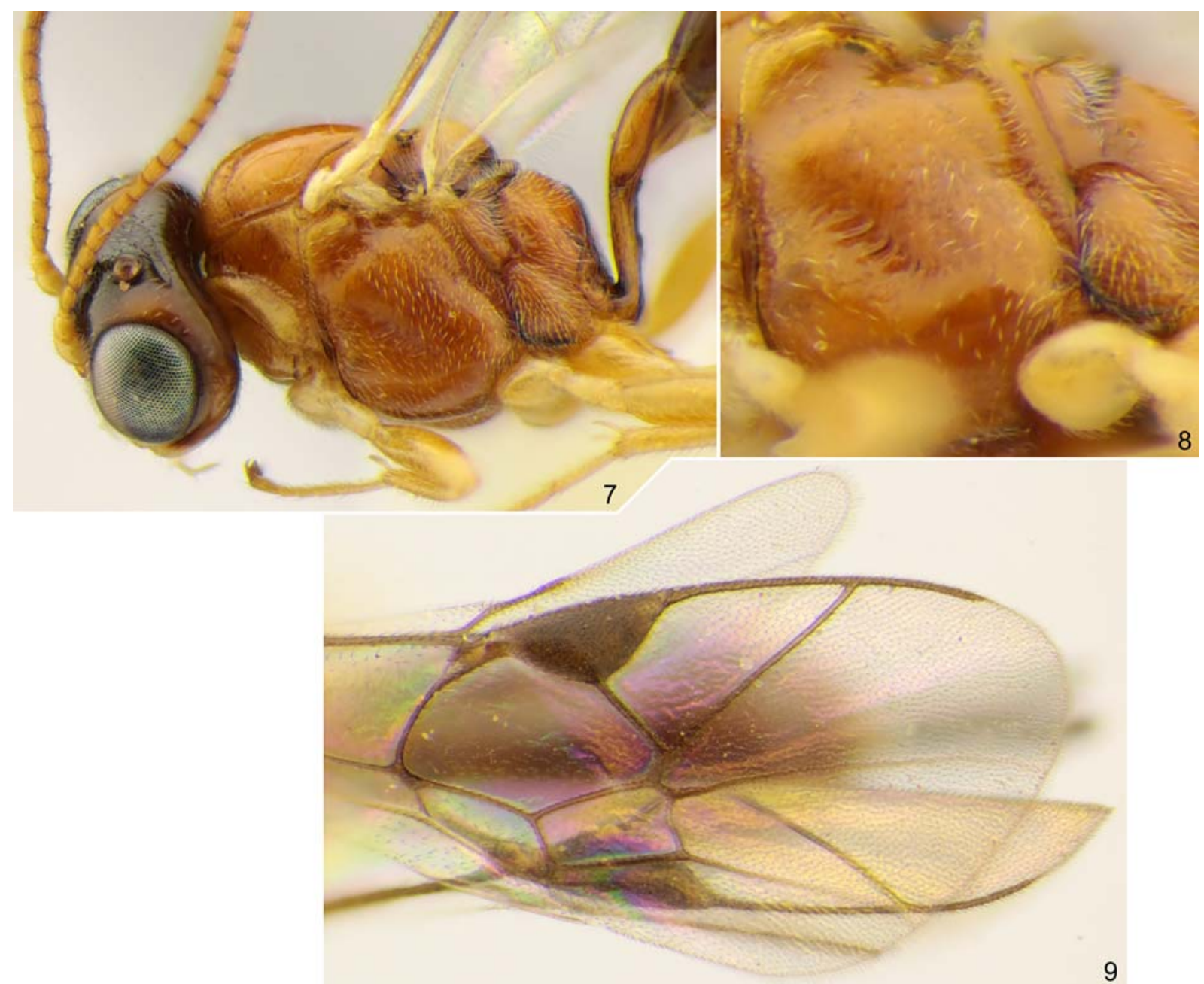

Figs 7-9. Australochus darreni sp.n., female, holotype: 7 - head, mesosoma and base of metasoma, lateral view; 8 - mesopleuron, ventro-lateral view; 9 - apex of fore wing.

Рис. 7-9. Australochus darreni sp.n., самка, голотип: 7 — голова, мезосома и основание метасомы, сбоку; 8 - мезоплевра, сбоку и снизу; 9 - вершина переднего крыла.

pterostigma. First and second abscissae of radius meeting at right angle. Metacarpus short, not reaching tip of fore wing. Hind wing with nervellus subvertical.

Legs robust, femora slightly thickened. Hind femur 3.0 times as long as broad and 0.7 times as long as tibia. Hind basitarsus 0.42 times as long as hind tibia. Spurs of hind tibia short, slightly curved apically. Tarsal claws not pectinate.

First metasomal tergite 2.6 times as long as posteriorly broad, depressed, trapeziform in cross-section in basal half, petiole laterally (before glymma) with shallow striae; postpetiole dorsally smooth, in dorsal view distinctly separated from petiole. Glymma large and deep (Fig. 7), joining by distinct furrow to ventral part of postpetiole, situated at midlength of first tergite. Second tergite transverse, 0.7 times as long as anteriorly broad. Thyridial depression short, distinctly transverse. Ovipositor slender, weakly and evenly upcurved, with two subapical teeth dorsally and three distinct teeth ventrally; sheath about 1.1 times as long as first tergite.

Head predominantly dark brown to black with pale marking on face centrally, on inner eye orbits at level of insertions of antennae and on upper eye orbits, and with lower parts of temple (next to mandibular bases) narrowly yellow (Figs 5 , 6); mouthparts, clypeus and mandible (teeth reddish brown) bright yellow. Antenna with scape and pedicel yellow; flagellum predominantly pale brown, ventrally yellowish (especially at base). Mesosoma predominantly brownish orange; propleuron and lower part of pronotum yellowish. Tegula yellow. Wings hyaline, pterostigma brown. Legs yellow, femora slightly brownish. Metasoma brownish orange, first tergite slightly paler than following ones.

Male. Unknown.

ETYMOLOGY. The species is named in honour of the New Zealand entomologist, Darren Ward (Auckland, New Zealand).

DISTRIBUTION. South Australia.

\section{Phradis tselikhae Khalaim, sp.n.}

Figs 10-17.

MATERIAL EXAMINED. Holotype: female, Australia, New South Wales, $20 \mathrm{~km} \mathrm{~S}$ of Deniliquin, Conargo, wandoo-forest, 14.IV.1978, coll. V.I. Tobias (ZISP).

Paratypes. South Australia, $220 \mathrm{~km} \mathrm{~N}$ of Port-Augusta, Flanders Mts, Wilpena, 30.IV.1978, coll. V.I. Tobias, 1 female (metasoma behind first tergite absent), 2 males (ZISP).

COMPARISON. The new species resembles $P$. nigritulus (Gravenhorst, 1829) occurring in the Palaearctic region as both 


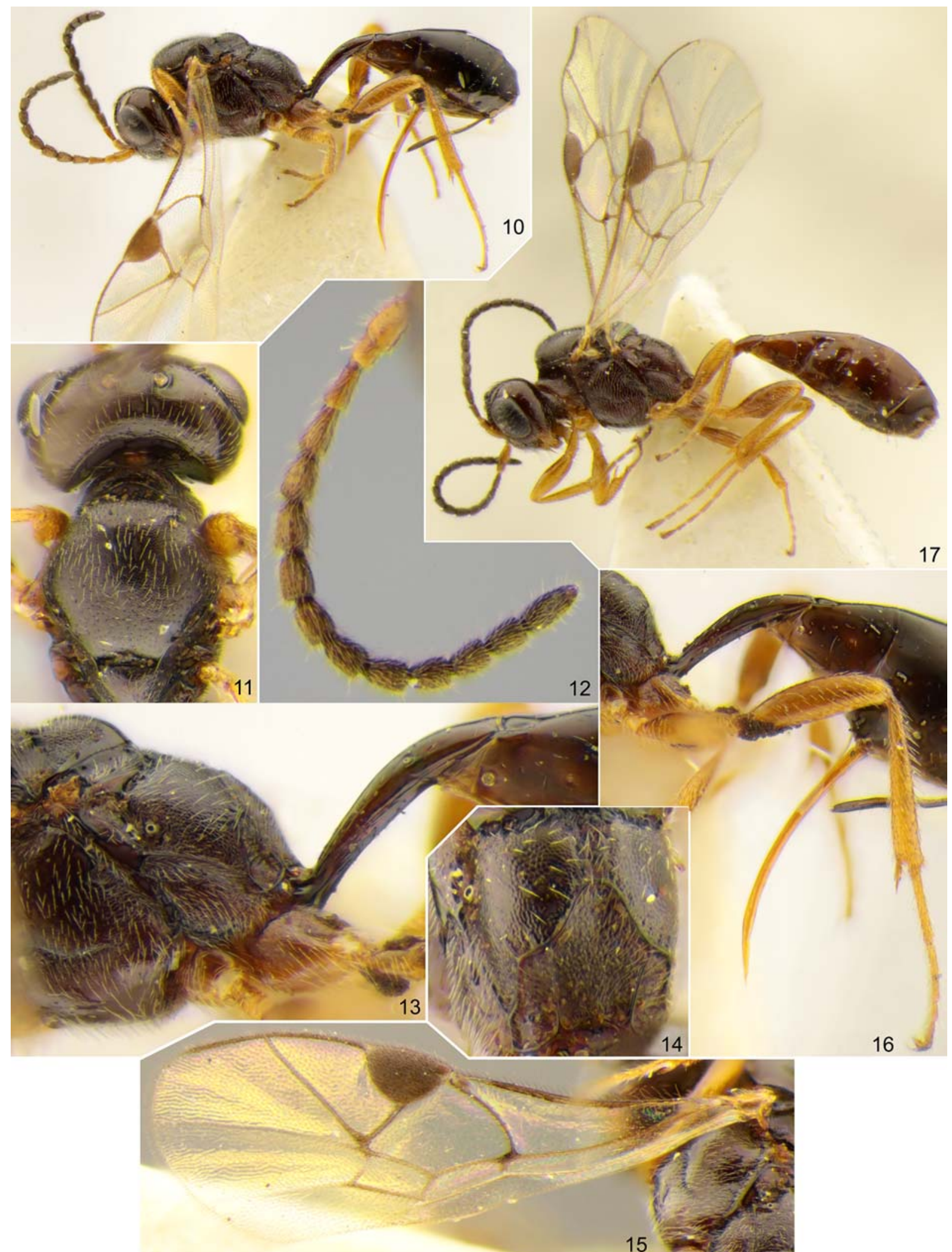

Figs 10-17. Phradis tselikhae sp.n., female, holotype (10-16) and male, paratype (17): 10, 17 — habitus, lateral view; 11 - head and mesoscutum, dorsal view; 12 - antenna, lateral view; 13 - posterior part of mesosoma and base of metasoma, lateral view; 14 - propodeum, dorsal view; 15 - fore wing; 16 - hind leg, lateral view.

Рис. 10-17. Phradis tselikhae sp.n., самка, голотип (10-16) и самец, паратип (17): 10, 17 — габитус, сбоку; 11 — голова и мезоскутум, сверху; 12 - антенна, сбоку; 13 - задняя часть мезосомы и основание метасомы, сбоку; 14 - проподеум, сверху; 15 переднее крыло; 16 - задняя нога, сбоку. 
have predominantly smooth and shining temple and mesopleuron, but differs from this species by mandible with upper tooth distinctly longer than the lower and a fewer number of antennal flagellomeres. Phradis tselikhae sp.n. also may be distinguished from all other species in this genus by the combination of its long temple, flagellum with 12 shortened flagellomeres, long and thin foveate groove on mesopleuron, and propodeum with furrow mediodorsally.

DESCRIPTION. Female. Body length $2.9 \mathrm{~mm}$. Fore wing length $2.3 \mathrm{~mm}$.

Head rounded behind eyes in dorsal view (Fig. 11); temple 0.95 times as long as eye width. Eyes glabrous. Clypeus lenticular, moderately broad, almost flat in lateral view, smooth and shining, with fine punctures in upper 0.3 , separated from face by thin and sharp groove. Mandible slender, weakly tapered towards apex, with upper tooth distinctly longer than the lower. Malar space almost 0.8 times as long as basal mandibular width. Antennal flagellum (Fig. 12) filiform, with 12 flagellomeres; flagellomeres 3 to 11 about 1.3-1.4 times as long as broad. Face with very weak convexity centrally. Face and frons with fine punctures on finely granulate background, dull. Vertex almost smooth, weakly shining, very finely punctate. Temple smooth and shining, impunctate. Occipital carina complete, mediodorsally slightly dipped. Hypostomal carina absent.

Mesoscutum granulate and finely punctate, dull (Fig. 11). Scutellum with lateral longitudinal carinae developed only at its extreme base. Notaulus with distinct wrinkle anterolaterally. Mesopleuron finely but disinctly punctate on smooth background, peripherally granulate. Foveate groove extending in anterior $0.7-0.8$ of mesopleuron, not reaching anterior margin of mesopleuron, upcurved anteriorly, rather thin, slightly widened anteriorly, with fine transverse wrinkles (Figs 10, 13). Propodeum (Fig. 14) granulate, dull, impunctate, mediodorsally with irregularly wrinkled furrow which is 0.6 times as long as apical area. Propodeal spiracle slightly enlarged, separated from pleural carina by $2.0-2.5$ times diameter of spiracle (Fig. 13). Apical area flat, rounded anteriorly; apical longitudinal carinae reaching transverse carina anteriorly (Fig. 14).

Fore wing (Fig. 15) with second recurrent vein interstitial to slightly postfurcal. Intercubitus moderately long, slightly thickened. First abscissa of radius 0.9 times as long as width of pterostigma. First and second abscissae of radius meeting at right angle. Metacarpus not reaching tip of fore wing. Hind wing with nervellus weakly reclivous, slanted about $10-15^{\circ}$.

Legs robust, femora slightly thickened. Hind leg (Fig. 16) with femur 3.7 times as long as broad and 0.85 times as long as tibia. Spurs of hind tibia short, more or less straight. Tarsal claws not pectinate.
First metasomal tergite 4.0 times as long as posteriorly broad, round in cross-section, smooth, with a few weak striae laterally; postpetiole weakly separated from petiole (tergite almost evenly widened from base to apex in dorsal view). Glymma absent (Fig.13). Second tergite 1.6 times as long as anteriorly broad. Thyridial depression 2.5-3.0 times as long as broad. Ovipositor slender, weakly and evenly upcurved, with shallow dorsal subapical depression (Fig. 16); sheath about 1.1 times as long as first tergite.

Body dark brown with reddish hue. Mouthparts, lower 0.7 of clypeus and mandible (teeth dark reddish brown) brownish yellow. Antenna with scape and pedicel yellow; flagellum pale brown basally to dark brown apically. Tegula brown. Wings hyaline, pterostigma brown. Legs predominantly brownish yellow; hind and sometimes mid coxae and femora darkened with brown.

Male. Antennal flagellum slenderer, weakly tapered towards apex, with 17 flagellomeres. Malar space shorter, 0.40.5 times as long as basal mandibular width. Otherwise similar to female.

ETYMOLOGY. The species is named in honour of the Russian entomologist, expert in Pteromalidae (Hymenoptera), Ekaterina V. Tselikh (ZISP).

DISTRIBUTION. South Australia.

ACKNOWLEDGEMENTS. I am thankful to John D. Oswald and Karen Wright (TAMU) for the loan of valuable material. This work was supported by the Russian Foundation for Basic Research (grant no. 16-04-00197).

\section{References}

Gauld I.D. 1984. Subfamily Tersilochinae. In: An Introduction to the Ichneumonidae of Australia // Bulletin of the British Museum (Natural History) (Entomology). Vol.895. P.304-316.

Khalaim A.I. 2004. New tersilochines from Australia and New Zealand (Hymenoptera: Ichneumonidae, Tersilochinae) // Zoosystematica Rossica. Vol.13. No.1. P.43-45.

Khalaim A.I. 2011. Tersilochinae of South, Southeast and East Asia, excluding Mongolia and Japan (Hymenoptera: Ichneumonidae) // Zoosystematica Rossica. Vol.20. No.1. P.96-148.

Khalaim A.I. 2015. To the study of Australian Tersilochinae (Hymenoptera: Ichneumonidae) // Russian Entomological Journal. Vol.24. No.1. P.77-83.

Yu D.S.K., van Achterberg C., Horstmann K. 2012. Taxapad 2012, Ichneumonoidea 2011. Database on flash-drive. Ottawa, Ontario, Canada. 